\title{
ENERGETIC AND KINETIC INVESTIGATION OF THERMALLY INDUCED MOLECULAR REARRANGEMENTS OF ESTERS OF (HYDROXYMETHYL) HYDRIDOSILANES BY DSC
}

\author{
S. Sarge ${ }^{1}, H$. K. Cammenga ${ }^{1}$, B. Becker ${ }^{2}$, R. Rohr-Aehle ${ }^{2}$ \\ and $R$. Tacke ${ }^{2}$ \\ 'INSTITUT FUR PHYSIKALISCHE UND THEORETISCHE CHEMIE DER TECHNISCHEN \\ UNIVERSITÄT BRAUNSCHWEIG, HANS-SOMMER-STR. 10, D-3300 BRAUNSCHWEIG, F.R.G.; \\ ${ }^{2}$ INSTITUT FUR ANORGANISCHE UND ANALYTISCHE CHEMIE DER TECHNISCHEN \\ UNIVERSITAT BRAUNSCHWEIG, HAGENRING 30, D-3000 BRAUNSCHWEIG, F. R. G.
}

\footnotetext{
Silanes of the type $\mathrm{R}^{1} \mathrm{R}^{2} \mathrm{Si}(\mathrm{H}) \mathrm{CH}_{2} \mathrm{OEI}(\mathrm{O})_{x} \mathrm{R}_{y}^{3}[\mathrm{R}=$ organyl; $\mathrm{El}=\mathrm{C}(x=y=1), \mathrm{S}(x=2, y=1)$, $\mathrm{P}(x=1, y=2)]$ undergo a thermally induced rearrangement to give silanes of the type $\mathbf{R}^{1} \mathrm{R}^{2} \mathrm{Si}$ $\left(\mathrm{CH}_{3}\right) \mathrm{OEl}(\mathrm{O})_{x} \mathrm{R}_{y}^{3}$. The energetic (reaction enthalpy) and kinetic data (reaction order, enthalpy and entropy of activation) of this reaction were determined by means of differential scanning calorimetry. The results obtained are discussed in terms of mechanistic aspects.
}

In the course of our studies [1-3] on the thermally induced molecular rear rangement of esters of (hydroxymethyl)hydridosilanes, some selected examples of this reaction type were studied by means of DSC using the compounds B1-B15 (see Table 1). The energetic and kinetic parameters obtained are discussed in terms of mechanistic aspects of the rearrangement.

\section{Synthesis and rearrangement of esters} of (hydroximethyl)hydridosilanes

Reaction of (hydroxymethyl)hydridosilanes $\mathbf{A}$ with acid chlorides or acid anhydrides yields the corresponding esters $B$ which undergo a thermally induced molecular rearangement to give compunds of type $\mathrm{C}$. In the case of carbonic ester chlorides B, the rearrangement is followed by decarboxylation to yield chlorosilanes of type $D$. The definite course of the reactions was checked by NMR spectroscopy ( ${ }^{1} \mathrm{H}$ NMR, $200 \mathrm{MHz}$ ). With only one exception (B11: solid), all compounds of the types B, C, and D are liquids. 
A<smiles>[R][Si]([R])([R])CO</smiles>

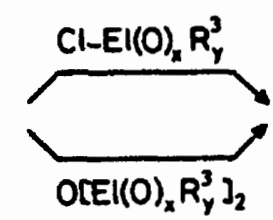

$R^{\prime}=$ Organyl; $R^{2}=$ Organyl,$H$

$$
E l= \begin{cases}C(x=1, y=1): & R^{3}=C_{3}, C l \\ S(x=2, y=1) ; & R^{3}=C_{3} \\ P(x=1, y=2) ; & R^{3}=C_{6} H_{5}\end{cases}
$$

B C

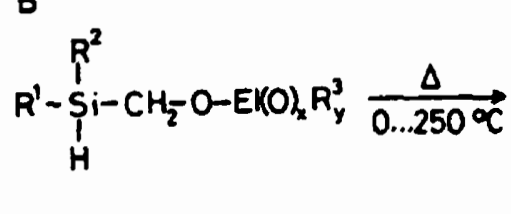<smiles>[R]O[Si]([R])([R])O[R]</smiles>
$-\mathrm{CO}_{2}\left\{\begin{array}{l}\mathrm{El}=\mathrm{C}, \mathrm{x}=\mathrm{y}=\mathrm{l} \\ \mathrm{R}^{3}=\mathrm{Cl}\end{array}\right.$<smiles>[R][Sb]([R])([R])C</smiles>

\section{Experimental conditions of the DSC measurements}

Two different types of differential scanning calorimeters were used to determine energetic (reaction enthalpy $\Delta_{r} H$ ) and kinetic data (reaction order $n$, energy of activation $E_{a}$ and frequency factor $k_{o}$ ) of the reaction $\mathrm{B} \rightarrow \mathrm{C}$ and $B \rightarrow C \rightarrow D:$ a standard heatflux calorimeter (Heraeus TA 500, Heraeus, Germany) and a modified Calvet-type calorimeter (MCB microcalorimeter, Thermanalyse, France). The MCB operated in a power-compensating mode; for this purpose the output of the thermopile was connected to a control amplifier with a proportional and integral characteristic [4].

Both instrument were connected to personal computers which control the instruments and collect the digitalized data (Heraeus: voltage related to the temperature difference between sample and reference sensors; MCB: current necessary to achieve temperature equilibrium between reference and sample cell). The personal computers were linked to the computer centre of the Technical University of Braunschweig where the evaluation of the experimental data took place.

In all cases hermetically' sealed sample containers (Heraeus: aluminium pans; MCB: glass ampoules) and empty reference containers were used. The heating rates were $1-10 \mathrm{deg} \min ^{-1}$ (Heraeus) and $0.5 \mathrm{deg} \min ^{-1}$ (MCB), respectively. The Heraeus calorimeter had been carefully calibrated with respect to calorimetric sensitivity and temperature determination by means of standards with exactly known melting points and heats of fusion [5], whereas the calibration factors of the MCB calorimeter equal unity because of its special construction and mode of operation. 


\section{Evaluation of the DSC data}

All experiments carried out consist of one DSC scan with sample and one DSC scan on identical conditions without sample. The subsequent evaluation took place as follows:

1. Measurement of the exothermic reaction peak.

2. Measurement of the instrumental baseline.

3. Subtraction of the baseline from the reaction curve:

$$
\left(\frac{\mathrm{d} q_{i}}{\mathrm{~d} t}\right)_{\text {corr }}=\left(\frac{\mathrm{d} q_{i}}{\mathrm{~d} t}\right)_{\text {reaction }}-\left(\frac{\mathrm{d} q_{i}}{\mathrm{~d} t}\right)_{\text {baseline }}
$$

4. Calculation of the first derivative of the curve with respect to time by gliding linear regression:

$$
\frac{\mathrm{d}}{\mathrm{d} t}\left(\frac{\mathrm{d} q_{i}}{\mathrm{~d} t}\right)_{\mathrm{corr}}=\frac{\sum_{j=i-7}^{i+7}\left(t_{j}-\bar{t}\right)\left[\left(\frac{\mathrm{d} q_{j}}{\mathrm{~d} t}\right)_{\mathrm{corr}}-\left(\frac{\mathrm{d} q}{\mathrm{~d} t}\right)_{\mathrm{corr}}\right]}{\sum_{j=i-7}^{i+7}\left(t_{j}-\bar{t}\right)^{2}}
$$

5. Deconvolution (elimination of thermal lag) by Tian's equation [6]:

$$
\left(\frac{\mathrm{d} q_{i}}{\mathrm{~d} t}\right)_{\mathrm{decon}}=\left(\frac{\mathrm{d} q_{i}}{\mathrm{~d} t}\right)_{\mathrm{corr}}+\tau \cdot \frac{\mathrm{d}}{\mathrm{d} t}\left(\frac{\mathrm{d} q_{i}}{\mathrm{~d} t}\right)_{\operatorname{corr}}
$$

6. Consideration of the enthalpy and temperature calibration functions of the instrument used:

$$
\begin{gathered}
\left(\frac{\mathrm{d} q_{i}}{\mathrm{~d} t}\right)_{H}=\frac{1}{E(T)}\left(\frac{\mathrm{d} q_{i}}{\mathrm{~d} t}\right)_{\mathrm{decon}} \\
T=T_{\exp }+\Delta T(T)
\end{gathered}
$$

7. Determination of the heat capacity change of the sample due to different heat capacities of educt and product. $\alpha$ is determined by an iterative procedure [7]:

$$
\left(\frac{\mathrm{d} q_{t}}{\mathrm{~d} t}\right)_{c_{p}}=(1-\alpha)\left(\frac{\mathrm{d} q_{i}}{\mathrm{~d} t}\right)_{H, \text { educt }}+\alpha\left(\frac{\mathrm{d} q_{t}}{\mathrm{~d} t}\right)_{H, \text { product }}
$$


8. Subtraction of the heat capacity curve from the calculated curve:

$$
\left(\frac{\mathrm{d} q_{i}}{\mathrm{~d} t}\right)=\left(\frac{\mathrm{d} q_{i}}{\mathrm{~d} t}\right)_{H}-\left(\frac{\mathrm{d} q_{i}}{\mathrm{~d} t}\right)_{c_{p}}
$$

9. Setting the limits for the reaction peak evaluation by eye.

10. Calculation of the molar reaction enthalpy by summation:

$$
\left(\frac{\mathrm{d} H_{i}}{\mathrm{~d} t}\right)=\frac{M}{m}\left(\frac{\mathrm{d} q_{i}}{\mathrm{~d} t}\right) \quad \Delta_{r} H=\sum_{i=i_{\text {start }}}^{i}\left(\frac{\mathrm{d} H_{i}}{\mathrm{~d} t}\right) \Delta t
$$

11. Calculation of the rate constant by the method of Borchardt and Daniels [8]:

$$
\begin{aligned}
& \Delta h_{i}=\underset{i=i_{\text {start }}}{\Sigma}\left(\frac{\mathrm{d} H_{i}}{\mathrm{~d} t}\right) \Delta t \\
& k_{i}=k_{o} \exp \left(-\frac{E_{a}}{R T_{i}}\right)=\frac{\mathrm{d} \alpha_{i} / \mathrm{d} t}{\left(1-\alpha_{i}\right)^{n}}=\frac{\mathrm{d} H_{i} / \mathrm{d} t}{\Delta_{r} H\left(1-\Delta h_{i} / \Delta_{r} H\right)^{n}}
\end{aligned}
$$

and determination of the kinetic parameters $n, E_{\mathrm{a}}$ and $\lg \left(k_{o}\right)$ by multiple linear regression [9]:

$$
\ln \left(\frac{\mathrm{d} \alpha}{\mathrm{d} t}\right)=\ln \left(k_{o}\right)-\frac{E_{a}}{R} \cdot \frac{1}{T}+n \ln (1-\alpha)
$$

12. When the reaction order is known, a linear regression of $k_{i}$ against $1 / T_{i}$ is performed (Arrhenius plot) [10]:

$$
\ln (k)=\ln \left(k_{o}\right)-\frac{E_{a}}{R} \cdot \frac{1}{T}
$$

13. The entropy and enthalpy of activation given in Table 1 were calculated from $k_{o}$ and $E_{a}$ with $n=1$ using the Eyring function [11]:

$$
\begin{aligned}
\Delta H^{\ddagger} & \simeq E_{a}-R T \\
\Delta S^{\ddagger} & =R\left[\ln \left(k_{o}\right)-\ln (T)-\ln \left(\frac{k_{B}}{h}\right)-1\right]
\end{aligned}
$$


SARGE ET AL.: ENERGETIC AND KINETIC INVESTIGATION

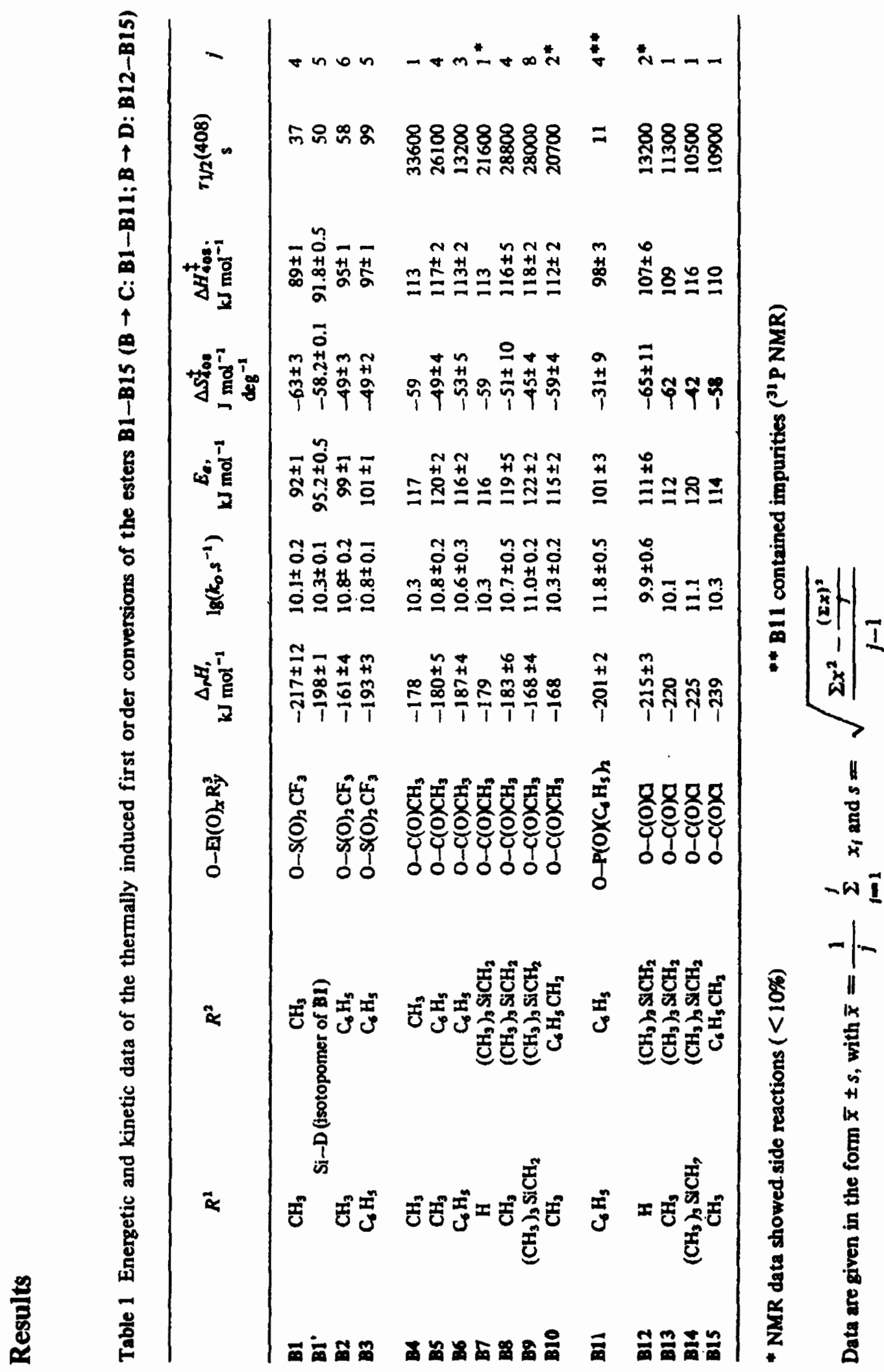


Discussion and conclusions

From the experimental results described here and from earlier findings [1-3] the following conclusions can be drawn:

- The rearrangement is exothermic (mainly determined by formation of the very strong $\mathrm{Si}-\mathrm{O}$ bond);

- the molecular rearrangement $\mathbf{B} \rightarrow \mathbf{C}$ and the conversion $\mathbf{B} \rightarrow \mathrm{D}$ (a rearrangement followed by a fast decarboxylation) follow a first order rate law;

- the reaction rate is strongly dependent on the $0-\mathrm{E} 1(0)_{x} \mathrm{R}_{y}^{3}$ moiety and significantly less dependent on the substituents $\mathrm{R}^{1}$ and $\mathrm{R}^{2}$ attached to the silicon atom and shows no significant effect on exchange of $H$ by $D$ $(\mathrm{SiH} / \mathrm{SiD})$;

- the $1,2-\mathrm{H}$ shift is an intramolecular process (evidence from cross experiments [1]);

- the entropy of activation is characterized by a very large negative value, indicating a highly ordered transition state;

- the results appear to be consistent with a mechanism which involves a migration of the $0-E l(0)_{x} R_{y}^{3}$ group from carbon to silicon as the rate determining step, followed by a fast 1,2-H shift (transition states of the type $\mathbf{E}$ and F, respectively, formula 2; by analogy with a model proposed for a formally analogous rearrangement, as described in ref. [12, 13]). Further experiments are planned to check this hypothesis.

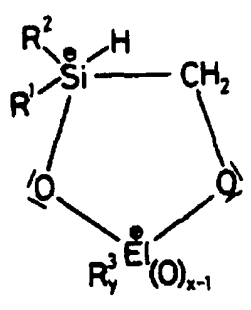

E

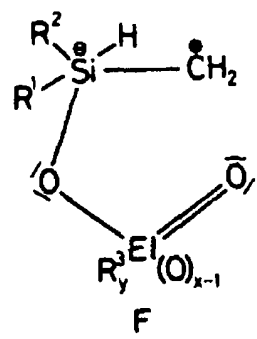

$F$

\section{List of simbols}

$\begin{array}{ll}\alpha & : \text { degree of conversion } \\ E & : \text { calorimetric calibration factor } \\ E_{a} & : \text { activation energy } \\ h & : \text { Planck constant }\end{array}$ 


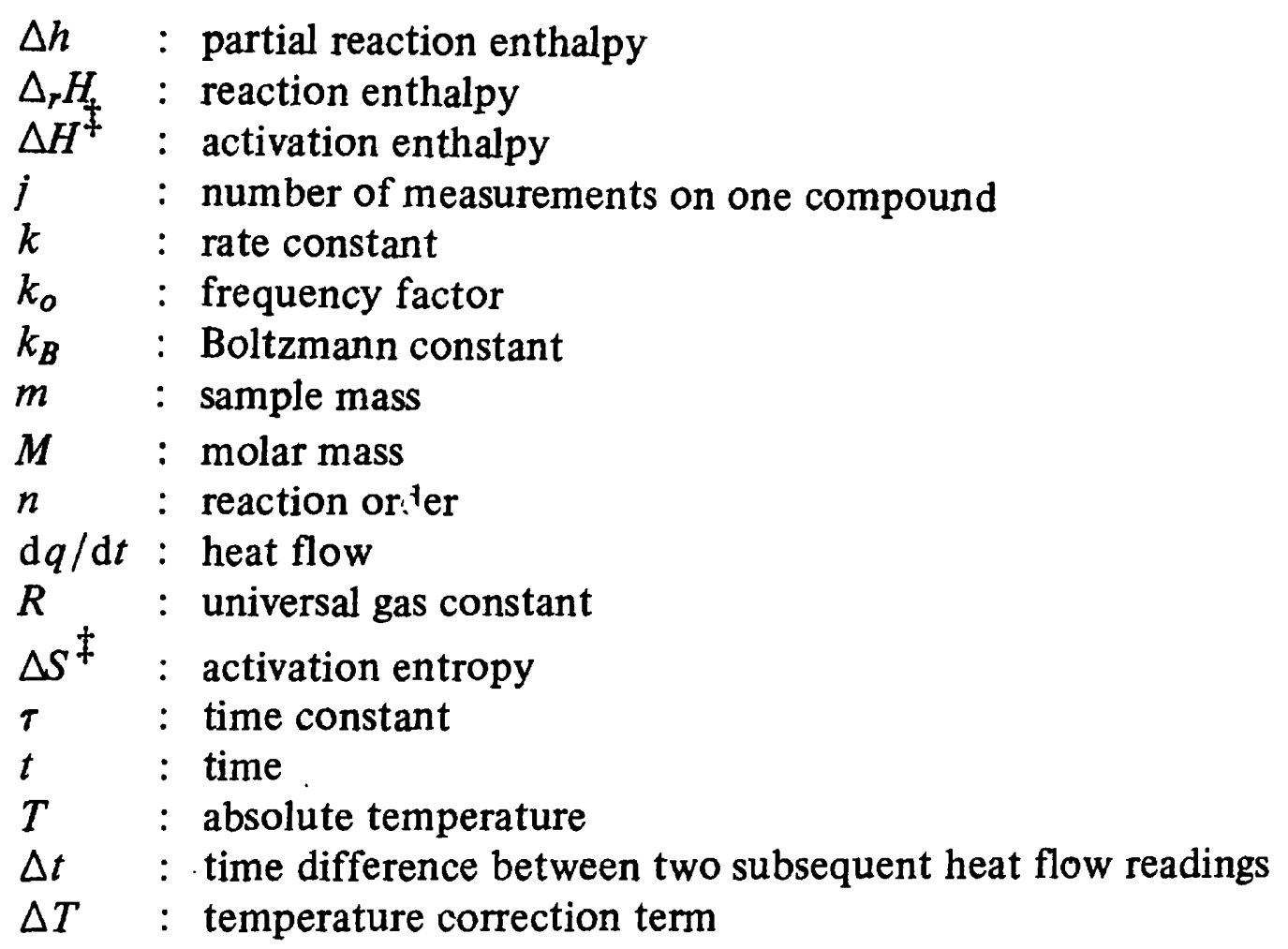

\section{References}

1 R. Tacke and H. Lange, Chem. Ber., 116 (1983) 3685-3691.

2 R. Tacke, M. Link, A. Bentlage-Felten, and H. Zilch, Z. Naturforsch., 40b (1985) 942$-947$.

3 R. Tacke, M. Link and $H$. Zilch, Chem. Ber., 118 (1985) 4637-4640.

4 J. Reichelt, Dissertation, TU Braunschweig, 1986, p. 86-95.

5 S. Sarge and H. K. Cammenga, Thermochim. Acta, 94 (1985) 17-31.

6 E. Calvet and H. Prat, Recent progress in Microcalorimetry, Pergamon Press, Oxford/ London/New York/Paris, 1963, p. 30-41.
7 U. Bandara, J. Thermal Anal., 31 (1986) 1063-1071.

8 H. J. Borchardt and F. Daniels, J. Am. Chem. Soc., 79 (1975) 41-46.

9 H. Wyden and G. Widmann, Experientia Suppl., 37 (1979) 284-290.

10 S. Arrhenius, Z. Phys. Chem., (Leipzig) 4 (1889) 226-248.

11 H. Eyring, Trans. Faraday Soc., 34 (1938) $41-48$.

12 A. R. Bassindale, A. G. Brook, P. F. Jones, and J. M. Lennon, Can J. Chem., 53 (1975 332-337.

13 M. T. Reetz and N. Greif, Angew. Chem., 89 (1977) 765-766. 
Zusammenfassung - Silane des Typs $\mathrm{R}^{1} \mathrm{R}^{2} \mathrm{Si}(\mathrm{H}) \mathrm{CH}_{2} \mathrm{OE} 10_{\mathrm{x}} \mathrm{R}_{\mathrm{y}}^{3}$ mit $\mathrm{R}=$ organyl; $\mathrm{El}=\mathrm{C}(x=y=1)$, $S(x=2, y=1)$ oder $\mathrm{P}(x=1, y=2)$ zeigen eine thermisch induzierte Umlagerung zu Silanen des Typs $\mathbf{R}^{1} \mathbf{R}^{2} \mathrm{Si}\left(\mathrm{CH}_{3}\right) \mathrm{OE} 10_{x} \mathbf{R}_{y}^{3}$. Energetische (Reaktionsenthalpie) und kinetische Daten(Reaktionsordnung, Aktivierungsenthalpie und entropie) dieser Umlagerungsreaktion wurden mittels DSC ermittelt. Die mechanistischen Aspekte der Ergebnisse werden diskutiert.

PE3ЮME - Силаны типа $\mathrm{R}^{\prime} \mathrm{R}^{2} \mathrm{Si}(\mathrm{H}) \mathrm{OE}(\mathrm{O})_{\mathrm{x}} \mathrm{R}_{\mathrm{y}}^{3}$, где $\mathrm{R}=$ органияескай радикеал, $\mathrm{El}=\mathrm{C}(x=y=1)$, $\mathrm{S}(x=2, y=1), \mathrm{P}(x=1, y=2)$, подверганотси термически наведенному превращенико с обрязованием силанов типа $\mathrm{R}^{1} \mathrm{R}^{2} \mathrm{Si}\left(\mathrm{CH}_{3}\right) \mathrm{OEl}(\mathrm{O})_{\mathrm{x}} \mathrm{R}_{y}^{3}$. C помошъ дСК были определены энергетические (энтальпшя реакши) и кинетические параметры (порядок реакции, энтаппия и энтропия активация) этой реакин. Полученные результаты обсуждены на основе механистических представлений. 